\title{
Penerapan Sistem Daring Terpadu dalam Proses Pengajuan Gugatan Perdata di Pengadilan dalam Upaya Peningkatan Pelayanan Publik
}

\author{
Lanny Lasama \\ Magister Studen, Faculty of Law, Parahyangan Catholic University \\ lanny.lasmana@gmail.com \\ Submitted: 2018-04-10; Reviewed: 2018-04-23; Accepted: 2018-04-30
}

\begin{abstract}
Each person has different means to handle and to settle disputes. Dispute settlement can be conducted through various means, among others non-litigation and litigation. Nonlitigation is conducted through the method of negotiation, mediation and consiliation, while litigation is conducted by going through the lane of civil lawsuit to the court. A dispute settlement process through the lane of civil lawsuit to the court requires a long process. Conventionally, civil lawsuit is submitted by the plaintiff against the defendant through the Chairperson of the Court at the domicile of the defendant. However, in the development, with the increase of cases submitted and registered with courts has led to long processes of lawsuit registration. Therefore, a breakthrough is needed for the registration processes of civil lawsuits at the courts to make registration more effective and efficient. On-line lawsuit registration could become a way out. This research is conducted by using the normative juridical method, supported by the sociological juridical method to complement it. The data used are secondary data consisting of primary, secondary and tertiary legal materials. While primary data are used as supporting data. The progress in technology and information opens the possibility to reduce and to optimize the integration of several functions, particularly the functions of the court registrar into one function. For instance, the receipt of dossiers of civil lawsuits can be conducted by online means, such is also with the registration of civil lawsuits. All those could be conducted without the need of meeting with the court registrar, dossier completion could be done online by by means of marking list of necessary matters (checklist) so that work efficiency can be achieved starting with the processof examination, summons, examination, and the making of minutes.
\end{abstract}

Keywords: Service online system; lawsuit; public service.

\section{PENDAHULUAN}

Hukum pada dasarnya diciptakan dengan tujuan agar di dalam masyarakat dapat terwujud keadilan, kemanfaatan dan kepastian hukum. Dalam proses penyelesaian sengketa, kepastian hukum seringkali menjadi hal yang utama bagi kepentingan para pihak. Salah satu mekanisme yang ditempuh oleh masyarakat dalam rangka memperoleh kepastian hukum, khususnya dalam perkara privat yaitu dengan melalui jalur litigasi. 
Proses litigasi di Indonesia mengacu kepada berbagai peraturan perundangundangan, antara lain KUHPerdata, HIR, RBG dan RV, serta peraturan perundangundangan lainnya.

Proses penyelesaian sengketa perdata, sekurang-kurangnya melibatkan dua pihak yaitu Pihak Penggugat (plaintif) yang mengajukan gugatan ${ }^{1}$, dan Pihak Tergugat (defendant). Penggugat adalah pihak yang merasa haknya telah dilanggar oleh pihak lain (tergugat), sedangkan Tergugat adalah pihak yang diduga telah melanggar hak orang lain. Proses litigasi ini menjadi jalan terakhir bagi para pihak dalam sengketa perdata untuk memulihkan hak privat sesorang yang telah dilanggar oleh orang lain, maka dilakukan upaya hukum melalui pengajuan tuntutan hak ke pengadilan dengan harapan, hakim dapat membantu memberikan putusan kepada mereka yang bersengketa. Tuntutan hak disebutnya sebagai tuntutan perdata (burgerlijke vordering $)^{2}$ yang dibuat atau dituangkan dalam bentuk surat gugatan.

Setiap orang pada dasarnya dapat mengajukan gugatan ke pengadilan. Namun demikian hal tersebut dibatasi, dalam arti hanya mereka yang mempunyai hubungan hukum sehingga mempunyai dasar untuk mengajukan gugatan. Agar suatu gugatan yang diajukan tidak keliru, maka dalam hal mengajukan gugatan Penggugat harus diajukan gugatan kepada badan pengadilan yang berwenang untuk mengadili persoalan tersebut.

Pada perkembanganya, kemajuan teknologi informasi yang terjadi sangatlah pesat, sehingga untuk memperoleh

\footnotetext{
${ }^{1}$ Di samping perkara gugatan, di mana terdapat pihak-pihak Penggugat dan Tergugat, ada juga perkara-perkara permohonan.
}

informasi dari segala penjuru dunia bukanlah suatu hal yang sulit lagi. Hal ini berdampak pula pada pengembangan pelayanan kepada publik khususnya terkait proses pengajuan gugatan ke badan peradilan. Penulis ingin mengkaji bagaimana gugatan yang dilakukan secara daring, diimplementasikan dalam praktik peradilan, tanpa menghilangkan hal-hal yang dipersyaratkan dalam gugatan perdata konvensional. Di samping itu, hal ini merupakan langkah inovasi dalam bidang teknologi dan informatika demi menunjang penegakan di bidang hukum dan peningkatan pelayanan publik. Inovasi ini dilakukan sebagai bentuk respons terhadap perubahan jaman ke dalam era digital.

\section{PEMBAHASAN}

\section{Gugatan dan Proses Pendaftarannya Dalam Sistem Hukum Indonesia}

Gugatan adalah suatu surat yang diajukan penggugat kepada Ketua Pengadilan (pada masing-masing badan peradilan yang meliputi Peradilan Umum, Peradilan Tata Usaha Negara, Peradilan Agama dan Peradilan Militer) yang berwenang, yang memuat tuntutan hak yang didalamnya mengandung sengketa dan merupakan dasar landasan pemeriksaan perkara dan suatu pembuktian kebenaran suatu hak, dengan kata lain pihak yang merasa dirugikan melayangkan surat gugatan kepada pihak yang telah merugikannya melalui pengadilan setempat. Penggugat melayangkan gugatan tersebut harus mempunyai alasan yang kuat, seperti adanya pelanggaran hak dan telah merugikan penggugat tuntutan hak, dengan

\footnotetext{
2 M Yahya Harahap, Hukum Acara Perdata, Jakarta: Sinar Grafika, 2015, hlm 48.
} 
tujuan memperoleh perlindungan hak dan kepastian hukum salah satu pihak yang diberikan oleh pengadilan untuk mencegah tindakan main hakim sendiri (eingenrichting). Artinya di antara para pihak harus ada suatu kepentingan yang cukup dan layak sehingga mempunyai dasar hukum untuk mengajukan tuntutan haknya tersebut ke pengadilan, dengan kata lain gugatan harus ditujukan kepada orang yang mempunyai hubungan hukum ${ }^{3}$ (asas legitima persona standi in judicio).

Dalam Herziene Inlandsch Reglement (HIR) dikenal 2 (dua) macam bentuk surat gugatan, yaitu gugatan tertulis dan gugatan lisan. Bentuk gugatan tertulis adalah yang paling utama. HIR pasal 118 ayat (1) atau pasal 142 Rechtsreglement voor de Buitengewestern $(\mathrm{RBg})$ menyatakan bahwa gugatan perdata pada tingkat pertama diawali dengan melakukan pendaftaran surat permohonan gugatan di yurisdiksi kompentensi tempat tinggal si tergugat (asas actor sequitor forum rei), atau domisilli hukum yang ditunjuk dalam perjanjian kepada kuasanya. Surat permohonan tersebut sudah ditandatangani oleh penggugat atau kuasanya, dan ditujukan kepada Ketua Pengadilan Negeri. Sedangkan bentuk gugatan lisan, diatur dalam Pasal 120 HIR atau Pasal 144 RBg memberikan kesempatan kepada mereka yang tidak cakap menulis atau buta huruf untuk bisa mengajukan gugatan secara lisan kepada Ketua Pengadilan Negeri

3 Yurisprudensi Putusan Mahkamah Agung Republik Indonesia Nomor 294.K/Sip/1971 tanggal 7 Juli 1971.

${ }^{4}$ Hal tersebut dapat kita lihat dalam Yurisprudensi Putusan Mahkamah Agung Republik Indonesia Nomor 396.K/Sip/1973 tanggal 4 Desember 1975 bahwa penggugat harus menyampaikan secara pribadi gugatan secara lisan dan tidak boleh diwakili oleh kuasanya. Hal tersebut juga ditemukan pada dengan mencatat gugatan atau memerintahkan seseorang untuk membuat catatan gugatan tersebut. Akan tetapi seorang advokat atau kuasa hukum tidak dapat mengajukan gugatan lisan. ${ }^{4}$

Ketentuan pasal di atas hanya dimaksudkan untuk penggugat yang tidak bisa membaca dan menulis tetapi bukan untuk orang yang buta hukum atau tidak memahami hukum juga kepada mereka yang memang tidak mampu untuk menggunakan jasa advokat atau kuasa hukum. ${ }^{5}$ Pada praktiknya, saat ini pihak penggugat atau diwakili oleh kuasanya melakukan pendaftaran dengan langsung membawa berkas surat gugatan ke pengadilan.

Mekanisme pengajuan gugatan menurut Pasal 118 (1) HIR, diajukan ke Pengadilan berdasarkan tempat tinggal tergugat atau domisili hukum yang ditunjuk dalam perjanjian (kompentensi relatif). Langkah kedua, penggugat membayar panjar biaya perkara. Beracara atau berperkara memerlukan biaya yang meliputi: biaya kepaniteraan, pemanggilan, pemberitahuan para pihak dan bea materai, dan sebagainya. Awalnya memang biaya perkara dibebankan kepada penggugat karena ia yang mendaftarkannya, kemudian di akhir persidangan, hakim memutuskan biaya perkara dibebankan kepada pihak siapa yang kalah. Langkah ketiga, penomoran registrasi perkara terhadap gugatan ke dalam Buku Register Perkara

Yurisprudensi Putusan Mahkamah Agung Republik Indonesia Nomor 195.K/Sip/1955 tanggal 28 November 1956 bahwasannya dalam hal gugatan secara lisan, tugas Hakim Pengadilan Negeri untuk menyempurnakan gugatan tulisan tersebut dengan jalan melengkapinya dengan petitum gugatan, sehingga dapat mencapai apa sebetulnya yang dimaksud oleh penggugat.

${ }^{5}$ M Yahya Harahap, Op.Cit, hlm. 48-49. 
untuk mendapatkan nomor gugatan sesuai dengan tanggal didaftarkannya gugatan tersebut. Setelah tercatat, maka Ketua Pengadilan Negeri memeriksa berkas dan menetapkan Majelis Hakim untuk memeriksa dan memutus perkara gugatan tersebut. Majelis Hakim terdiri tiga orang hakim dengan komposisi seorang Hakim Ketua Majelis dan dua orang lainnya sebagai Hakim Anggota. Majelis Hakim yang terbentuk kemudian menetapkan hari sidang dan melakukan pemanggilan (relaas) para pihak untuk hadir pada hari yang telah ditentukan tersebut.

Pengajuan gugatan yang selama ini berjalan adalah masyarakat atau yang mewakilinya melakukan pendaftaran melalui cara konvensional ini (secara langsung mendatangi kantor Pengadilan Negeri setempat dan bertemu dengan Panitera guna mencatatkan gugatan tersebut). Setiap surat gugatan yang dicatatkan di pengadilan disebut di register, kemudian surat gugatan menjadi arsip perkara. Setiap hari bila dilihat banyaknya pendaftaran gugatan maka arsip perkara pun kian hari kian banyak menumpuk di setiap ruangan kearsipan dan ruangan penerimaan perkara. Seperti yang terjadi pada Kantor Pengadilan Agama Surabaya ; menurut mereka, kebutuhan buku register gugatan dengan volume perkara rata-rata 750 perkara perbulan, maka tiap bulan membutuhkan sampai 3 buku, berarti pertahun bisa lebih dari 36 buku register gugatan, begitu pula dengan buku register induk keuangan perkara, buku register permohonan, buku jurnal dan lain-lain. Belum lagi arsip berkas perkara yang rata- rata 8000 perkara pertahun, dalam satu rak terdapat enam tingkat, diperkirakan dalam satu tahun 6 bulan sudah penuh. Sehingga lambat laun semua ruangan di Pengadilan Agama Surabaya penuh dengan arsip manual. ${ }^{6}$

Untuk itu diperlukan terobosan baru untuk meminimalisirkan penumpukan berkas, kehilangan berkas ataupun hal lainnya dengan mengarah kepada arsip perkara secara terkomputerisasi. Teknologi penyimpanan (filling) terhadap informasi sehingga mempermudah menyimpanan berkas. Keuntungan menggunakan digital dalam mengkelola arsip tentu akan mengurangi beban kerja dan memaksimalkan kerja sumber daya manusia (SDM), mempercepat pekerjaan dan tidak membutuhkan ruangan yang luas untuk menyimpannya.

Terobosan baru tidak hanya digital arsip tetapi sudah beberapa pengadilan yang juga melakukan inovasi baru dengan menerima gugatan secara daring. Selama ini masyarakat terbiasa dengan cara yang konvensional yang cenderung memakan waktu, menyadari hal tersebut diperlukan suatu terobosan ide yang berkembang dari pemanfaatan teknologi dengan diciptakannya suatu Sistem Daring Terpadu, dalam penerapannya sistem ini tentu saja tidak keluar dari koridor yang diamanatkan oleh aturan-aturan hukum di Indonesia.

\section{Konsep Pendaftaran Gugatan Di Pengadilan Dengan Sistem Daring}

Sejak tahun 2003 Mahkamah Agung telah menjadikan transparansi sebagai bagian

\footnotetext{
6 https://pa-surabaya.go.id/pa/index.php/item/5dari-manual-menuju-digital, diakses tanggal 3 Maret pukul 12:23 WIB
} 
cetak biru (blue print) pembaruan Mahmakah Agung RI. Salah satu bentuk dari transparansi adalah dengan memberikan jaminan bahwa publik diberikan keleluasaan untuk mengakses informasi. ${ }^{7}$ Dengan adanya transparansi peradilan, secara perlahan akan terjadi penguatan akuntabilitas dan profesionalisme serta integritas warga peradilan. $^{8}$

Sejalan dengan perkembangan jaman, dimana era digital sudah banyak dipahami masyarakat. Teknologi informasi menjadi andalan untuk menyelesaikan tugas dan fungsi banyak hal. Justru dengan hadirnya teknologi informasi dan era digital, pengadilan membuka diri menerima pembaharuan peradilan memberikan nilai tambah dan dampak positif untuk meningkatkan pelayanan kepada masyarakat.

Teori produktivitas George J. Washin, penerapan sistem daring terpadu pada pengajuan gugatan perdata menggunakan dua konsep utama, yaitu efisiensi dan efektivitas. Efisiensi mengukur tingkat sumber daya, baik manusia, keuangan, maupun alam yang dibutuhkan untuk memenuhi tingkat pelayanan yang dikehendaki, efektivitas mengukur hasil mutu pelayanan yang dicapai. Pengajuan gugatan perdata secara online mencakup keseluruhan proses pendaftaran gugtan di pengadilan, di mana kehadiran sistem ini diharapkan dapat mempermudah masyarakat untuk mengakses, mengetahui

\footnotetext{
${ }^{7}$ http://bawas.mahkamahagung.go.id/portal/images/ stories/Informasi_Publik/sk20kma20ri20no.20114420ttg20pedoman20layanan20informasi20di20p engadilan.pdf, diunduh tanggal 3 Maret 2018, pukul 10:46 WIB.

8 https://www.pn-bantul.go.id, diakses tanggal 3 Maret 2018, pukul 11:28 WB.
}

sekaligus mengawasi proses gugatannya. Penerapan sistem daring terpadu ini merupakan suatu inovasi untuk meningkatkan pelayanan publik dimana masyarakat dapat dengan mudah mengakses dan memantau kelanjutan perkara tindak pidana sehingga menciptakan efisiensi dan efektivitas penanganan perkara.

Daring atau komunikasi dalam jaringan Komunikasi daring (online) adalah cara berkomunikasi dimana penyampaian dan penerimaan informasi atau pesan dapat dilakukan dengan menggunakan internet atau melalui dunia maya (cyberspace). Internet adalah media komunikasi yang cukup efektif dan efisien dengan tersedianya berbagai layanan fasilitas seperti web, chatting (mIR chat, yahoo massanger, gtalk, dll), email, friendster, facebook, dan twitter. 9 Melalui perkembangan daring, setiap lini dan sektor kehidupan masyarakat, telah menjadikan semua persoalan dapat ditangani secara mudah dan cepat, melalui sistem yang berbasiskan teknologi. Beberapa aktivitas yang saat ini sering digunakan seperti: internet banking, belanja online, melamar pekerjaan, dan sebagainya. APJII (Asosiasi Penyelenggara Jasa Internet Indonesia) telah mengumumkan hasil survei Data Statistik Pengguna Internet Indonesia tahun 2016. Jumlah pengguna internet di Indonesia tahun 2016 adalah 132,7 juta atau sekitar $51,5 \%$ dari total jumlah penduduk Indonesia. ${ }^{10}$

\footnotetext{
${ }^{9}$ https://bnet.id/1242-2/, diunduh pada hari senin, tanggal 2 April 2018, Pukul 12.45 WIB.

10 http://isparmo.web.id/2016/11/21/data-statistikpengguna-internet-indonesia-2016/, diakses tanggal 2 Maret 2018, pukul 11:33 WIB.
} 
Pada tahun 2017, jumlahnya meningkat menjadi 143,26 juta pengguna/user. ${ }^{11}$ Data tersebut tentunya memberitahukan kepada kita bahwa rakyat Indonesia sudah semakin banyak melek menggunakan komunikasi secara daring.

Tuntutan jaman yang sudah berubah, dengan gaya hidup tidak lagi menggunakan kertas/paperless. Penggunaan kertas dalam korespondensi sudah menurun sejak tahun 1990, sebagian pencatatan dilakukan secara elektronik. 12 Menurut penulis, perkembangan teknologi ini bisa juga dipergunakan dalam bidang hukum seperti:

a. Memungkinkan pengiriman data dalam jumlah banyak secara efisien, ekonomis, relatif cepat, dan lebih pasti, tepat sasaran tanpa tercecer;

b. Dukungan pemantauan jarak jauh, sehingga memungkinkan penggugat mengetahui perkaranya dari daring;

c. Penggunaan daring secara terpusat, sehingga mendukung efisiensi manajemen pengadilan, baik desentralisasi ataupun sentralisasi.

Integrasi komunikasi melalui komputer dalam mengajukan gugatan secara daring ke pengadilan memiliki beberapa keunggulan jika dibandingkan dengan komunikasi konvensional, antara lain sebagai berikut:

a. Penggugat mendaftarkan gugatan secara daring kapan saja dan bisa dilakukan dimana saja (di rumah ataupun di kantor).

b. Berbeda dengan komunikasi

${ }^{11} \mathrm{https}: / /$ ekonomi.kompas.com/read/2018/02/19/16 1115126/tahun-2017-pengguna-internet-diindonesia-mencapai-14326-juta-orang, diakses tanggal 2 Maret 2018, pukul 11:36 WIB. konvensional, komunikasi daring tidak memerlukan pihak penggugat untuk bertemu tatap muka, tentunya dapat menghemat biaya transportasi.

c. Komunikasi dapat dilakukan dengan cepat tanpa harus membuang waktu dengan melakukan perjalanan. Surat gugatan dapat disampaikan pada saat itu juga dalam hitungan detik walaupun penggugat dengan panitera saling berjauhan. Dalam proses pengajuan gugatan melalui daring ini, Penggugat/Kuasa Hukumnya akan mendapatkan username dan password, yang hanya diketahui oleh si Penggugat/Kuasanya, terkait adanya informasi atau pemberitahuan lainnya yang disampaikan oleh panitera pengadilan/juru sita di dalam laman (web) pengadilan sebagaimana dimaksud.

d. Kelengkapan lain (Biaya Panjer Perkara yang telah dibayarkan melalui bank, KTP, Kartu Advokat, Berita Acara Sumpah, Bukti Pembayaran, SKTM) dalam pengajuan gugatan dapat diajukan melalui mekanisme unggah (upload) data yang telah pindai (scan) terlebih dahulu.

e. Panggilan sidang (relaas) tidak memerlukan biaya, mengingat panggilan ini akan diberitahukan melalui daring, di mana pihak panitera pengadilan akan

${ }^{12}$ https://www.kompasiana.com/kangrahmat/memb angun-paperless-

office 552df4006ea8347d7f8b4582, diakses tanggal 2 Maret 2018, pukul 11:45 WIB. 
menyampaikan kepada Penggugat dan Tergugat melalui fitur tersendiri mengenai relaas sidang.

f. Melakukan komunikasi daring, juga memanfaatkan layanan teknologi informasi lainnya untuk mendukung pelaksanaan dan kelengkapan gugatan tersebut. Seperti : pelaksanaan sidang melalui panggilan konferensi (video conference).

Adapun landasan hukum yang digunakan dalam penerapan pengajuan melalui mekanisme daring, antara lain: ${ }^{13}$

a. Undang-Undang Nomor 48 Tahun 2009 tentang Kekuasaan Kehakiman;

b. Undang-Undang Nomor 3 Tahun 2009 jo Undang-Undang Nomor 5 Tahun 2004 tentang Perubahan Kedua Undang-Undang Nomor 14 Tahun 1985 tentang Mahkamah Agung;

c. Undang-Undang Nomor 8 Tahun 2004 jo Undang-Undang Nomor 49 Tahun 2009 tentang Perubahan Kedua Undang-Undang Nomor 2 Tahun 1986 tentang Peradilan Umum;

d. Undang-Undang Nomor 25 Tahun 2009 tentang Pelayanan Publik Standar Pelayanan meliputi elemen waktu, biaya, dan kualitas pelayanan;

e. HIR (Herziene Inlandsch Reglement);

f. PERMA RI Nomor 3 Tahun 2012;

g. PERMA RI Nomor 7 Tahun 2015;

h. Keputusan KMA RI Nomor

${ }^{13}$ https://perkara.info/, diakses tanggal 26 Maret 2018, pukul 10:33 WIB.
032/KMA/SK/IV/2006;

i. SEMA RI Nomor 3 Tahun 1998

j. SEMA 14 tahun 2010 tentang Dokumen Elektronik sebagai Kelengkapan Permohonan Kasasi dan Peninjauan Kembali;

k. SK KETUA MA No. 138 KMA/SK/IX/2009 tentang Jangka Waktu Penangan Perkara di MA;

1. Peraturan SEKMA RI Nomor 2 Tahun 2012.

\section{Kendala dan Solusi Pengajuan Gugatan Melalui Sistem Daring}

Pelaksanaan penerapan pengajuan gugatan melalui mekanisme daring tentunya akan dihadapkan pada beberapa kendala, antara lain:

a. Dalam pelaksanaan proses pengajuan gugatan secara daring tentunya memerlukan perangkat secara khusus. Untuk itu pengadilan memerlukan anggaran menyediakan perangkat keras/hardware dan perangkat lunak/software yang menyediakan layanan pengajuan gugatan secara daring.

b. Perubahan ke era teknologi yang begitu cepat membawa dampak pada kesiapan para penegak hukum memanfaatkan teknologi, yang mana mereka tentunya harus update diri yang lebih berkualitas bagaimana menggunakan teknologi. Didukung oleh SDM (Sumber Daya Manusia), sebagai penyelenggara pelayanan hukum yang profesional berwawasan maju diharapkan kepada mereka para 
penegak hukum untuk memiliki integritas moral yang tinggi.

c. Sarana Prasarana pengadilan hukum yang representatif, seperti persiapan perangkat yang semuanya serba digital. Belum meratanya infrastuktur yang mendukung teknologi di setiap pengadilan, karena seharusnya dibangun bersamaan di setiap pengadilan agar terkoneksi. Optimalisasi perangkat teknologi dan informasi di pengadilan sehingga mudah dipergunakan oleh pengguna teknologi.

d. Keamanan data dan sistem agar tidak ada ancaman bisa mengakses secara tidak sah jaringan, merubah atau menambahkan data oleh peretas (cyber crime). Sistem daring terpadu dirancang secara rahasia (confidential), sehingga hanya penggugat dan juga pihak pengadilan yang mengetahuinya.

e. Dengan adanya sarana prasarana berbasis teknologi maka akan ada biaya pemeliharan untuk semua hal itu.

Berdasarkan pemaparan di atas, badan peradilan dalam hal ini peradilan tingkat pertama, terus berusaha melakukan pembaharuan di segala bidang baik teknis maupun non teknis berkaitan erat dengan tuntutan masyarakat akan kemandirian hukum dan keadilan, penegakan supremasi hukum, proses peradilan yang cepat, sederhana, dan biaya ringan terhadap lembaga peradilan, meningkatkan sumber daya aparatur peradilan dalam rangka peningkatan pelayanan pada masyarakat, melaksanakan tertib administrasi dan manajemen peradilan yang efektif dan efesien, serta mengupayakan tersedianya sarana dan prasarana peradilan sesuai dengan ketentuan yang berlaku.

Mengacu pada cetak biru yang dibuat oleh Mahkamah Agung secara ideal dapat diwujudkan: ${ }^{14}$

a. Melaksanakan fungsi kekuasaan kehakiman secara independent, efektif, dan berkeadilan;

b. Didukung pengelolaan anggaran berbasis kinerja secara mandiri yang dialokasikan secara proporsional dalam APBN;

c. Memiliki struktur organisasi yang tepat dan manajemen organisasi yang jelas dan terukur;

d. Menyelenggarakan manajemen dan administrasi proses perkara yang sederhana, cepat, tepat waktu, biaya ringan dan proporsional;

e. Mengelola sarana prasarana dalam rangka mendukung lingkungan kerja yang aman, nyaman, dan kondusif bagi penyelenggaraan peradilan;

f. Mengelola dan membina sumber daya manusia yang kompeten dengan kriteria obyektif, sehingga tercipta personil peradilan yang berintegritas dan profesional;

g. Didukung pengawasan secara efektif terhadap perilaku, administrasi, dan jalannya peradilan;

h. Berorientasi pada pelayanan publik yang prima;

i. Memiliki manajemen informasi

14 https://www.mahkamahagung.go.id/media/198, diunduh tanggal 3 Maret 2018, pukul 20:18 WIB. 
yang menjamin akuntabilitas, kredibilitas, dan transparansi;

j. Modern dengan berbasis teknologi infomasi terpadu.

Perbaikan sistem peradilan terutama dengan menggunakan kecanggihan teknologi diperlukan untuk membantu mengoptimalisasikan kinerja lembaga peradilan dengan tujuan untuk meningkatkan efisiensi dan efektifitas pengadilan agar dapat melakukan suatu proses perkara secara efektif dan efisien. Program modernisasi pengelolaan gugatan perkara perdata sebagai salah satu langkah untuk menuju modernisasi peradilan. Salah satu prasyarat penting dalam penerapan pengajuan gugatan melalui mekanisme daring yaitu adanya kemauan politik atau political will pemerintah untuk mewujudkannya. Hal tersebut dapat kita lihat dari inisiatif lembaga peradilan melakukan upgrade dalam beberapa hal pelayanan kepada publik. Dimulai dari lembaga peradilan yang berada di kota besar sampai dengan kota kecil telah banyak mengalami perubahan dalam hal pelayanannya. Di samping itu, perlu adanya regulasi yang mengatur khusus terkait dengan penerapan pengajuan gugatan melalui mekanisme daring sebagai landasan hukum, serta untuk memudahkan para penegak hukum dalam melaksanakan kebijakan sebagaimana dimaksud. Di sisi lain, pemerintah perlu menyediakan anggaran yang cukup di dalam APBN guna menyediakan sarana dan prasarana terkait penerapan pengajuan gugatan melalui mekanisme daring.

Pendidikan dan pelatihan atau bimbingan teknis untuk meningkatkan kualitas daripada sumber daya aparaturnya menjadikan hal yang tidak dapat dikesampingkan, mengingat berkembangnya mekanisme daring tidak terlepas dari peran SDM yang akan melaksanakannya, serta pemberian remunerasi dan tunjangan yang memadai bagi SDM tersebut. Instrument lain yang perlu ditingkatkan, yaitu perlunya sosialisasi yang intensif agar masyarakat memahami perkambangan yang terjadi dalam proses pengajuan gugatan secara daring di Pengadilan.

\section{PENUTUP}

Pelaksanaan penerapan sistem daring terpadu pada dasarnya dilakukan guna meningkatkan pelayanan publik, khususnya dalam proses pengajuan gugatan di Pengadilan. Beberapa pengadilan di Indonesia telah mengakomodasi pengajuan gugatan melalui mekanisme daring, contohnya Pengadilan Jakarta Pusat. Pelayananan dengan memanfaatkan teknologi dan informasi tidak terlepas dari political will pemerintah dan lembaga peradilan, yang akhirnya proses tersebut ditujukan agar dapat menciptakan efisiensi dari mulai proses melakukan gugatan secara perdata sampai dengan putusan hakim. Kendala yang dihadapi adalah keterbatasan sumber daya manusia, dan sarana prasarana pendukung, keamanan data, dan biaya pemeliharaan sarana dan prasarana. Sistem daring terpadu ini nantinya akan terintergrasi se-Indonesia dan sistem ini dibuat sederhana, penggugat mempunyai akun (account) tersendiri.

Untuk itu perlu solusi yang dapat ditawarkan, yaitu : regulasi yang mengatur terkait penerapan gugatan secara daring, tersedianya anggaran yang cukup untuk 
memoderenisasi sarana dan prasarana pendukung terintergrasi se-Indonesia dan tentunya dengan perawatan sistem komputerisasi tersebut. Pendidikan dan pelatihan bagi SDM yang akan melaksanakan sistem daring di Pengadilan. Hadirnya Sistem Daring Terpadu dimulai dari proses pengajuan gugatan perdata diharapkan memudahkan masyarakat untuk mengakses, mengetahui sekaligus mengawasi proses gugatan ini hingga tahap hasil putusan hakim.

\section{DAFTAR PUSTAKA}

\section{Buku}

M Yahya Harahap, Hukum Acara Perdata, Jakarta: Sinar Grafika

\section{Perundang-undangan}

Herziene Inlandsch Reglement (HIR)

Rechtsreglement voor de Buitengewestern (RBg)

\section{Rujukan Internet}

https://bnet.id/1242-2/

http://bawas.mahkamahagung.go.id/portal/ images/stories/Informasi_Publik/sk20k ma20ri20no.201-

14420ttg20pedoman20layanan20infor masi20di20pengadilan.pdf

https://ekonomi.kompas.com/read/2018/02 /19/161115126/tahun-2017-penggunainternet-di-indonesia-mencapai-14326juta-orang http://isparmo.web.id/2016/11/21/datastatistik-pengguna-internet-indonesia2016/

https://klc.kemenkeu.go.id/wpcontent/uploads/2016/08/2-HukumAcara-Perdata.pdf https://www.kompasiana.com/kangrahmat/ membangun-paperless- office_552df4006ea8347d7f8b4582

https://www.mahkamahagung.go.id https://pa-surabaya.go.id https://perkara.info/ https://www.pn-bantul.go.id 